\title{
İzmir balık hali çalışanlarının mesleki sağlık ve iş kazaları üzerine bir ön çalışma
}

\section{A preliminary study on occupational health and accidents in İzmir fish market workers}

\author{
Okan Akyol ${ }^{*}$ - Tevfik Ceyhan M. Akif İçlik \\ Ege Üniversitesi Su Ürünleri Fakültesi 35440 Urla, Izmir, Türkiye \\ *Corresponding author: okan.akyol@ege.edu.tr
}

How to cite this paper:

Akyol, O., Ceyhan, T. \& İlik, M.A. (2016). A preliminary study on occupational health and accidents in İzmir fish market workers (in Turkish with English abstract). Ege Journal of Fisheries and Aquatic Sciences, 33(2): 109-112 . doi: 10.12714/egejfas.2016.33.2.03

\begin{abstract}
Öz: Bu çalışmada, İzmir balık hali çalışanlarının sağlık sorunları, halde iş güvenliği ve halin bazı sosyal ve fiziki şartları ortaya konmuştur. Çalışmanın verileri Ekim 2013 - Mayıs 2014 tarihleri arasında İmir balık halinde bazı çalışanlarla yapılan anketler $(\mathrm{n}=35)$ sonucu elde edilmiştir. Ayrıca kurum doktoruyla da görüşülmüştür. Sonuçta, halin hijyen konusunda yetersiz kaldığı, sosyal alanların kısıtlı olduğu, iş güvenliğinin ve verilen eğitimlerin ise yetersiz olduğu ortaya çıkmıştır. Balık halleri açısından Iş Sağlığı ve Güvenliği çok yeni bir konudur. Bu nedenle de bazı aksakııklar gözlemlenmiştir. Iş Sağlığı ve Güvenliğinin acilen ele alınarak balık hallerindeki eksikliklerin giderilmesi büyük önem arz etmektedir.
\end{abstract}

Anahtar kelimeler: Balık hali, personel, sağlık, iş kazası, güvenlik

Abstract: : This study presents to the health problems, work safety and some social and physical conditions of Izmir wholesale fish market's employees. The data were obtained from the questioners with workers $(n=35)$ between October 2013 and May 2014. Additionally, we interviewed with medical doctor of institution. We determined that there were lack of hygiene, social conditions, work security and safety courses in the market. Occupational safety and health is a new issue for fish markets in Turkey. Because of that, paucities have been observed. It must urgently be handled and elimination of paucities is very important.

Keywords: Wholesale fish market, personnel, health, industrial injury, security

\section{GíRiş}

Dünya nüfusunun giderek artmasıyla birlikte, oluşan protein açığını karşılayacak miktar ve kalitede gıda temini endişeleri de her geçen gün artmaktadır. Balığın zengin bir hayvansal protein kaynağı olmasının yanı sıra içerdiği doymamış yağ asitleri sayesinde hayvansal proteinin en sağlıkı kaynağı olan su ürünleri tüketimi giderek önem kazanmaktadır. Su ürünlerinin yüksek ihracat potansiyeline sahip olması, balık unu/yağ sanayi sektörüne hammadde teşkil etmesi, gıda güvenliğinin önemli bir unsuru haline gelmesi ve önemli istihdam oluşturması gibi hususlarda her geçen gün önemi daha da artmaktadır.

Türkiye'de 2013 yılı su ürünleri üretimi 607.515 ton olarak gerçekleşmiş olup, bunun 374.121 tonu avcllık, 233.394 tonu yetiştiricilik yoluyla elde edilmiştir (TÜIK, 2014). Elde edilen su ürünlerinin büyük bir kısmı balık halleri aracılığıyla iç pazara sunulmaktadır. Türkiye de günümüzde 13 adet su ürünleri toptan satış yeri bulunmaktadır. İstanbul'da bulunan bir özel girişim hariç, tüm su ürünleri satış yerleri belediyeler tarafından kurulmuş ve işletilmektedir (BSGM, 2012).

İzmir balık hali, Türkiye'nin İstanbul'dan sonraki ikinci büyük halidir. Hal, Buca Kaynaklar mevkiinde 1997 yılından bu yana faaliyet göstermektedir. Halde çalışan memur sayısı 10, toplam personel sayısı 89'dur. İdari bina iki kattan oluşmaktadır. Balık hali 68 dönüm arazi üzerinde $5.000 \mathrm{~m}^{2}$ açık alan ve $5.000 \mathrm{~m}^{2}$ kapalı satış yerinden oluşmaktadır. Halin şehir merkezine uzaklığı yaklaşı 20 km'dir. Halde 3 adet soğutucu depo, 4 adet şoklama $\left(-20^{\circ} \mathrm{C} /-40^{\circ} \mathrm{C}\right)$ ünitesi, 12 idari büro ile 43 adet ticari büro bulunmaktadır. Ayrıca 3 adet tuvalet, 1 adet duş bulunmaktadır. 1000 araç kapasiteli otoparkı bulunan halde, elektronik mezat, perakende satış ünitesi, arıtma tesisi, konferans salonu, tamirat odası, sağlık odası ve laboratuvar bulunmamaktadır (Yıldırım ve Akyol, 2012).

Bugün itibariyle ülkelerin en büyük sermayeleri vasıflı işgücüdür. Günümüzde teknolojinin hızla ilerlemesine, makineleşmeye ve yeni üretim yöntemlerine rağmen, eğitim yetersizliği, işe yabancılaşma ve işyerine ait olma duygusunun 
zayıflaması gibi nedenlerle iş kazaları ve meslek hastalıkları sonucunda yaşanan maddi ve manevi kayıplar ürkütücü boyutlara ulaşmıştır. Bu nedenle temel hedef, iş kazaları ve meslek hastalıklarını baştan önleyici tedbirler almak ve bu konularda bilgi sahibi olup, gerekli İş Sağlığı ve Güvenliği (ISG) eğitimlerinden geçmek olmalıdır. Nitekim ILO kaynaklarına göre her yı 1,2 milyon kişi iş kazaları ve meslek hastalıkları nedeniyle hayatını kaybetmektedir. Yine aynı kaynaklara göre her yıl 250 milyon kişi iş kazaları, 160 milyon kişi ise meslek hastalıkları sonucunda zarara uğramaktadır (Bıyıkçı, 2010).

Norveç iş teftiş kurumu tarafından yapılan çalışmalarda su ürünleri sektöründe meydana gelen iş kazalarının nedenleri sırasıyla, makine, kayma-düşme, kesici aletler, kimyasallar, bot-tekne kazaları, iğne batması, yüksekten düşme, göz yaralanmaları ve diğerleri olarak sıralanmıştır (Mert ve Ercan, 2014 atfen Mayers ve Durborow, 2012 )

Türkiye'de iSG konusu henüz çok yenidir ve 6331 sayılı Iş Sağlığı ve Güvenliği Kanunu 30 Haziran 2012'de Resmi Gazetede (Sayı: 28339) yayımlanarak yürürlüğe girmiştir. Türkiye'nin iş kazaları açısından Avrupa birincisi olduğu haberleri sıklıkla medyanın gündemine gelmektedir. Hem iş kazaları hem de meslek hastalıkları açısından yapılan çalışmalar ise yok denecek kadar azdır. Balıkçılık ve meslek hastalıkları/kazaları hususunda; bir su ürünleri işleme tesisinde iş sağlığı ve güvenliği risk analizi konusunda Atayeter ve Terzioğlu (2009); küçük ölçekli balıkçıların iş sağlığı ve iş kazaları üzerine bir çalışma Perçin vd. (2012); su ürünleri sektöründe iş sağlığı ve güvenliği uygulamaları konusunu kapsayan bir çalışma ise Mert ve Ercan (2014) tarafından gerçekleştirilmiştir.

Bu ön çalışmada, İzmir Balık Hali çalışanlarının, mevcut sağlık sorunları ve iş kazaları çeşitliliğinin belirlenmesi ve çalışanların bazı sosyo-demografik özelliklerinin ortaya konması amaçlanmıştır.

\section{MATERYAL VE YÖNTEM}

Araştırma, Ekim 2013 - Mayıs 2014 tarihleri arasında İzmir balık halinde aralıklı beş çalışmayla yürütülmüştür. Bu dönemdeki balık halinin fiziksel ve sosyal durumu, personel sağlığı, halin çalışma koşullarının belirlenmesi için hal müdürü, bazı hal çalışanları (hamal, depocu, temizlikçi, şoför, vb.) ve komisyonculardan oluşan 35 kişi (tüm çalışanların \%35'i) ile yüz yüze anketler yapılmış, kurum doktoruyla da görüşülerek mevcut sağlık sorunları hakkında bilgi alınmıştır. Anket, rastgele seçilmiş ve anket yapmaya gönüllü personele doğum yeri, tarihi, diğer mesleği, haldeki görevi, işkolu, mesleki tecrübesi, çalışma saati, izin durumları, gelirleri, medeni durumu, eğitimi, barınma, sosyal güvencesi, kronik hastalığı olup olmadığı, doktora gitme sıklığı, alkol/sigara kullanımı, iş kazası geçirip geçirmediği, iş kazası çeşidi, vb. toplam 45 soruyu içermektedir. Elde edilen sonuçlar, oransal ve aritmetik ortalamalarla $( \pm \mathrm{SH})$ değerlendirilmiş olup, istatistiki olarak önem düzeyleri tek örneklem $\chi 2$ testi ve tek örneklem binominal testi ile değerlendirilmiştir.

\section{BULGULAR}

Halde İzmir Büyükşehir Belediyesine bağlı Eşrefpaşa Hastanesi tarafından tahsis edilmiş bir adet sağlık görevlisi bulunmaktadır. Tüm personel Eşrefpaşa Belediye Hastanesi'nde altı ayda bir genel sağlık kontrolüne tabi tutulmaktadır. Ankete tabi tutulan personelin bazı sosyodemografik özellikleri Tablo 1'de özetlenmiştir.

Tablo 1. İzmir balık hali çalışanlarının bazı sosyo-demografik özellikleri (parantez içerisindekiler minimum ve maksimum değerlerdir, ort.: ortalama; SD: Standard sapma)

Table 1. Some socio-demographic properties of wholesale fishmarket's employees (in paranthesis shown that min. and max. values, ort.: mean; SD: standard deviation)

\begin{tabular}{|c|c|}
\hline Özellikler & $\mathrm{n}=35$ \\
\hline Personelin tecrübesi (yıl, ort. $\pm S D$ ) & $9,8 \pm 1,1(3-25)$ \\
\hline Hane halkı sayısı (ort. $\pm S D)$ & $4,1 \pm 0,4(1-11)$ \\
\hline Baktığı kişi sayısı (ort. $\pm S D)$ & $3,1 \pm 0,4(0-10)$ \\
\hline Günlük çalışma süresi (saat, ort.さSD) & $8,5 \pm 0,2(6-10)$ \\
\hline Tüm geliri balıkhaneden olan (\%) & 77,1 \\
\hline Evli (\%) & 77,1 \\
\hline Ev sahibi (\%) & 57,1 \\
\hline \multirow[t]{3}{*}{ Gelir memnuniyeti (\%) } & 34,3 \\
\hline & 51,4 \\
\hline & 14,3 \\
\hline \multirow[t]{4}{*}{ Sosyal güvence (\%) } & 82,9 \\
\hline & 17,1 \\
\hline & - \\
\hline & - \\
\hline \multirow[t]{3}{*}{ Sosyal üyelik (\%) } & 18,9 \\
\hline & 51,4 \\
\hline & 29,7 \\
\hline \multirow[t]{5}{*}{ Eğitim (\%) } & 37,1 \\
\hline & 22,9 \\
\hline & 22,9 \\
\hline & 8,6 \\
\hline & 8,6 \\
\hline
\end{tabular}

Balık hali çalışanlarının \%77,1'i maaşla, \%8,6'sı payla, $\% 8,6$ 'sı hasılat ortağı ve \%5,7'si ise haftalıkla çalışmaktadırlar. Gelir elde etme yöntemleri arasındaki fark istatistiki olarak önemli bulunmuştur $(p<0,05)$. Aynı zamanda çalışanların gelir memnuniyeti arasında da istatistiki olarak önemli fark bulunmaktadır $(p<0,05)$.

Minimum 6 saat, maksimumum 12 saat çalışan personelin çalışma saatleri arasındaki fark istatistiki olarak önemlidir $(p<0,05)$. Eğitim düzeyleri açısından irdelendiğinde ise ilkokul mezunlarının istatistiki olarak önemli oranda balık halinde görev yaptığı tespit edilmiştir $(p<0,05)$.

Balık hali çalışanlarının \%34,3'ü sadece sigara tüketirken, $\% 5,7$ 'si sadece alkol; \%25,7'si hem sigara hem alkol tüketmekte; \%34,3'ü ise ne sigara ne alkol tüketmektedir (Şekil 1). Alkol tüketim sıklığı oldukça az olmakla beraber (haftada veya ayda bir gibi), sigara tüketimi ise günlük $1 / 2$ paket ile 1 paket arasında ifade edilmiştir. 


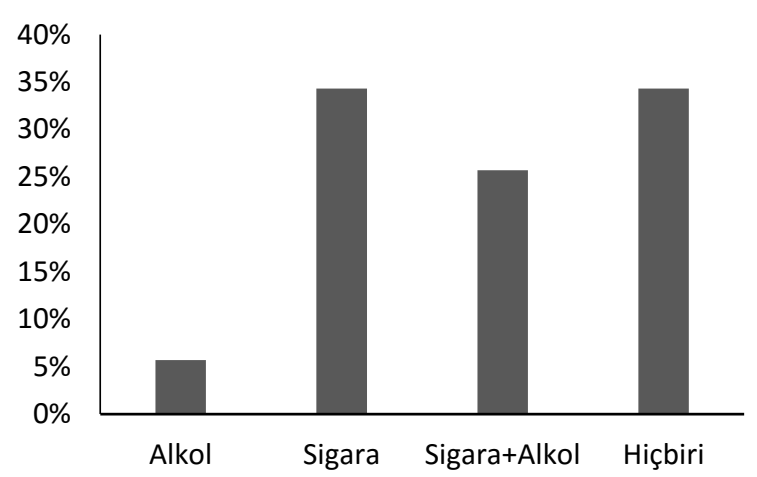

Şekil 1. Balık hali çalışanlarının sigara ve alkol tüketim oranları Figure 1. The ratio of cigarette and alcohol consumptions of workers

Balık hali çalışanlarının \%11,4'ünün kronik rahatsızlığ (tansiyon, menüsküs, romatizma, astım) olduğu tespit edilmiş olup, tüm çalışanların \%80'ininin doktora gittiği, doktora gidiş sıklığının ise oldukça seyrek olduğu; \%46,4 'ünün sadece hastalanınca doktora gittiği, \%25'inin ise yılda bir gittiği tespit edilmiştir.

Hal çalışanlarına düzenli tahlil olarak kan, idrar ile röntgen çekimi ve mantar-hepatit testi yapılmasının yanında bu çalışmada saptanan genel sağlık problemleri Tablo 2'de gösterilmiştir. Buna göre en çok rastlanan hastalık tipi \% 45,7 ile kas-iskelet sistemi hastalıklarıdır. Genel hastalıklar dışında göz, işitme, ürolojik, sindirim sistemi gibi diğer kronik rahatsızıklar da bazı çalışanlarda mevcut olmakla birlikte çok düşük frekansılı olduğu için detaylandırılmamıştır.

Tablo 2. İzmir balık hali çalışanlarında rastlanan hastalık tipleri Table 2. Illness types of wholesale fishmarket's employees

\begin{tabular}{lc}
\hline Hastalık & $\mathrm{N}(\%)$ \\
\hline Kas-iskelet sistemi rahatsızlıkları & $16(45,7)$ \\
Cilt rahatsızlıkları & $12(34,3)$ \\
Solunum sistemi rahatsızlıkları & $5(14,3)$ \\
\hline
\end{tabular}

Hal çalışanlarının \%54,3'ü yaptıkları işin sağlıklarına zararı olduğunu düşünmektedir. İs kazaları bakımından 13 kişi $(\% 37,1)$ küçük ya da büyük bir iş kazası geçirdiğini ifade etmiş; bunlardan üçü ciddi yaralanmaya (incinme, ezilme, çatlak) maruz kalmıştır. Yaralanma ve düşmelerin kayma, kasa ve buz kalıbının ayağa düşmesi şeklinde gerçekleştiği tespit edilmiştir.

Iş güvenliği şartları bakımından halin durumunu, çalışanların \%22,9'u iyi bulurken, $\% 62,9^{\prime}$ 'u orta, $\% 14,3^{\prime}$ ü ise kötü bulmaktadır. İ̧ kazaları ile ilgili eğitim ve bilgilendirme toplantılarının halde bazen (nadiren) yapıldığını belirtenlerin oranı $\% 77,1$ 'dir. Bu eğitim ve seminerler daha çok iş güvenliği uzmanı tarafından yapılmakla birlikte, bazen belediye, sendika ve kurum doktorunca yapııdığı ifade edilmiş̧tir.
Çalışanlar, halin sosyal şartlarını orta ve kötü olarak $(\% 88,6)$ değerlendirmektedir. Halde çıkan yemekler ise genellikle orta-iyi olarak $(\% 91,4)$ değerlendirilmiştir.

\section{TARTIŞMA VE SONUÇ}

Türkiye'nin işlem hacmi bakımından İstanbul'dan sonra en büyük ikinci su ürünleri hali olan İzmir balık hali çalışanları üzerine yapılan bu ön çalışmada, halin fiziki şartları, mevcut sağık ve kaza problemleri ile halin sosyal şartları çalışanların görüşleriyle ortaya konmuştur.

Balık halinde genellikle düşme, çarpma, kesilme, burkulma gibi iş kazaları sıkıkla meydana gelmektedir. Atayeter ve Terzioğlu (2009), düşme kaynaklı kazaların yarısının merdivenden düşme, nakliye/taşıma kazalarının ise ağırlıklı olarak forklift kaynaklı olduğunu saptamışlardır. Buna ilaveten et ve balık sektörlerinde yaralanma sebepleri arasında; kesikler, ezilmeler, burkulmalar ve kırıkların ön plana çıktığını; en çok etkilenen organlar olarak da parmak, el, ayak bileği, kol ve gözler olarak bildirmişlerdir. Halde iSG eğitiminin nadir olarak verildiğini ifade edenler $(\% 77,1)$ büyük çoğunluktadır. Aynı zamanda, balıkhane gibi zor çalışma şartlarının mevcut olduğu yerlerde işçi giriş-çııı̧̧ı da oldukça fazla olmaktadır. Bu durum, pek çok kişinin ISG eğitimini alamadan (ya da eğitime denk gelmeden) çalışıyor olduğu anlamına gelmektedir. İzmir balık hali bünyesinde, İzmir Büyükşehir Belediyesine bağlı iş güvenliği uzmanı, işyeri hekimi bulunmasına rağmen, halde işyeri sağlık ve güvenlik birimi ile acil müdahale odası bulunmamaktadır.

Halde balık nakliyeleri halen el arabaları ile yapılmakta bu nedenle işçilerde ergonomik açıdan rahatsızı|klar meydana gelebilmektedir. Çalışanlarda çoğunlukla kas, kemik, eklem, cilt rahatsızlı̆ı gibi sağlık sorunları yaşanmaktadır. Bu durum, ağır kasa kaldırmaları, soğuk ve nemli ortam, iş kıyafetlerine önem vermeme, vb. sebeplerden oluşmaktadır. Çalışanların en az $\% 60$ 'ı sigara tüketmekte ve buna bağlı solunum sistemi rahatsızı|kları tüm rahatsızlıklar içerisinde üçüncü sırayı almış bulunmaktadır.

Halde işçilere sorumluluğu dışında birden fazla iş yaptırımakta; bu durum ise çalışanlar üzerinde fiziksel ve psikolojik sorunlar yaratabilmektedir. Çalışanlar, çalışma koşullarının ağırlı̆ı̆ndan ve uyku problemlerinden sıkça bahsetmektedir. Çalışmanın erken saatlerde başlaması (sabah 05.00) olumsuz etki yapmakta, kronik uyku (insomnia) problemlerine neden olmakta, işin ağırlığı çalışanlar üzerinde meslek hastalıklarına ve çalışma isteğinin kaybolmasına neden olmaktadır. Ayrıca uykusuzluk durumu dalgınlığa (dikkat eksikliği) bağı iş kazalarına da davetiye çıkarabilmektedir.

Zeminden kaynaklanan ve yeterli bilgilendirme tabelası kullanılmamasından dolayı kayma ve düşmeye bağıı sakatııklar sıklıkla oluşabilmekte, sonuçta ciddi rahatsızlıklara ve süresi belirsiz iş kayıplarına neden olabilmektedir. Ticari büro elemanları ve diğer iş̧̧iler çalışma esnasında uygun kıyafet giymemektedirler. Oysa bu iş için başı koruyucu baret, ucu çelik 
koruyuculu bot ya da çizme, Islanmaz tulum, kaymaz eldiven, vb. iş kıyafetleri zorunlu hale getirilmelidir.

Mezat alanında ısıtma sisteminin etkin kullanılamamasından dolayı özellikle kış aylarında üşütmeye bağlı sağlık sorunları meydana gelebilmekte ve iş kayıplarına neden olmaktadır. Halin genel satış alanında soğuk zincir gereği ısıtıcı bulunmamakta, sadece büro gibi kapalı ortamlarda personel için ısınma sağlanabilmektedir.

Perrçin vd. (2012), Ege Denizi küçük ölçekli balıkçılarının benzer olarak özellikle kas-iskelet sistemi rahatsızlıklarından (\%84) muzdarip olduklarını bildirmişlerdir. Ayrıca, denizde çalışan balıkçıların bu çalışmaya göre çok daha yüksek oranda alkol (\%68) ve sigara (\%72) kullandıkları ortaya konmuştur.

Halin temizlenmesinde dezenfektan kullanılmamakta sadece su ve deterjan ile temizlik yapılmakta, aynı zamanda tahta kasa kullanımının halen devam ettiği görülmektedir. Bu durum şüphesiz mikroorganizmaların ortamda çoğalmasının nedeni sayılabilir. Hali Hazırda su ürünleri toptan ve perakende satış yerleri yönetmeliğinin ( Resmi Gazete Tarihi: 19.06.2002, Resmi Gazete Sayısı: 24790) 11-c maddesine göre "hal içerisinde tahta kasa veya doğrudan ürünlerle temas eden

\section{KAYNAKÇA}

Atayeter, S. \& Terzioğlu, E. (2009). Application of occupational health and safety risk analysis in a fishery processing plant (in Turkish with English abstract). GIDA, 34 (5); 287-293.

Bıyıkçı, E.T. (2010). Occupational safety expertise to ensuring of occupational health and safety (in Turkish with English abstract). Uludağ Üniversites Sosyal Bilimler Enstitüsü, Y.L. Tezi, Bursa, $108 \mathrm{~s}$.

BSGM (2012). Fish wholesale locations (in Turkish). http://www.bsgm.gov.tr, Erişim tarihi (12 Kasım 2012)

Mert, B. \& Ercan, P. (2014). Evaluation of occupational health and safety practices in aquaculture industry (in Turkish with English abstract). Türk Bilim Araştırma Vakfı, TÜDAV Bilim Dergisi, 7(4); 16-27. yerlerde, alet ve ekipmanlarda tahtadan üretilmiş malzemeler kullanılmamalıdır" denmektedir. Buna ilaveten, Yıldırım ve Akyol (2012), İzmir balık halinde ahşap kasa kullanımı ile bazı hijyen kurallarının (antiseptik banyo, uygun kıyafet, çöp depolama, araçtan satış, vb.) tam uygulanmamasından bahsetmişlerdir. Geçen birkaç yıllık süreye rağmen, bu sorunların halen devam ettiği görülmektedir.

Hal bünyesinde sadece restoran ve büfeden oluşan sosyal alanlar çalışanların intiyaçlarını tam olarak karşılayamamakta, sosyal alanların yetersizliği çalışanların hoşnutsuzluğuna (\%89) neden olmaktadır.

Sonuçta, İzmir balık hali yıllık işlem hacmi 40000 tonu geçen önemli bir balık hali olmasına rağmen, ISG, hijyen ve sanitasyon, sosyal şartlar hususlarında yeterli olmadığı görülmektedir. Sağlık sorunlarının izlenmesi ve ISG konusunda gerekli eğitimlerin nadiren gerçekleştirildiği ifade edildiğinden, bu hususta acilen tedbirlerin alınması, yeterli eğitimlerin sıklıkla yerine getirilmesi, tüm çalışanlara yılda en az iki defa sağlık taraması yapılması, hatta hal içerisinde tam zamanlı çalışan doktorun bulunduğu bir revir kurulması, halin sosyal şartlarının iyileştirilmesi gerekliliği açıktır.

Perçin, F., Akyol, O., Davas, A. \& Saygı, H. (2012). Occupational health of Turkish Aegean small scale fishermen. Occupational Medicine, 62:148151. doi: $10.1093 /$ occmed/kgr181

TÜIK (2014). Fishery Statistics 2013. Türkiye İstatistik Kurumu, Ankara, Eylül $2014,61 \mathrm{~s}$.

Yıldırım, B.R. \& Akyol, O. (2012). İzmir wholesale fish market: current status, fish amounts (2007-2011) and problems. (in Turkish with English abstract) Ege Journal of Fisheries and Aquatic Sciences, 29(4):151-155. doi: 10.12714/egejfas.2012.29.4.01 